\title{
SUBSIDIES TO PRIVATE THEATERS
}

\author{
Sacit Hadi AKDEDE ${ }^{1}$
}

\begin{abstract}
Subsidies to private theatres are one of the main cultural policy problems of many countries. Increasing the number of audience is an important priority of many countries' cultural policies. Private theatreas like public theatres are important cultural entities to increase the number of audience in many countries. The main goals of public theatres can be also met by private theatres if the governmet subsidies them. In addition, private theatres can serve very well to the cultural diversity of countries. State theatre, in politically polarized countries like Turkey, can not provide cultural diversity since they can not produce political plays. If government draws a good defined cultural subsidy program, it can provide fiscal aid to any theatre that meets the requirements of subdity program. Market structure of private theatres all over the world is close to perfect competion. It is not monopoly, but monopolistic comptetition. If the number of private theatres is increasing, it does not mean that the market becomes competely capitalistic. Theatre sector is not like cinema, TV, or media sector. There are more private theatres than public theatres in more developed countries and most of them get government subsidy from central and local governments.
\end{abstract}

Keywords: Theatres, government subsidy, economics of art and culture, private theatres.

JEL Code: Z01, Z11.

\section{Introduction}

The Turkish State Theaters (TST) produced plays with budgets far above the aid provided to private theaters. TST had the halls and scenes where they could rehearse and produce plays, hang promotional posters on many boards of the city, easily promoted and sold tickets at prices that would create unfair competition. Sometimes the number of guests without a ticket exceeds the number of sold tickets (with a ticket). Most of the private theaters had not had a theatre hall to rehearse their plays, most of them did not even have a small space ( a small hall or a reasonable size room) to rehearse. As they did not have a fixed hall to rehearse and perform, they could not sustain or provide continuity, therefore could not create their own audience. In this case it seems to be that state led to a crowding-out effect. Generally, public infrastructure investments can create crowding-in effect since it reduces the fixed costs of private investment, while more crowding-out situations have emerged here because the state has not built new theaters and did not let the private theatres use existing state theatre buildings. However, private theaters can use the state's theater buildings for both rehearsals and shows on certain days of the week. Of course, in this case, a new repertoire choice and the issue of the change of production policy regime will arise. Some theater halls are not suitable and can not be used in heavy decors. This new situation can force TST to produce plays with light décor, and other technical constraints. In this case, competition will also emerge. Otherwise, TST seems to be superior in average spectator's eye and it has been unfairly competitive according to private theaters with its heavily decorated or glamorous scenery. This privileged position, which is provided to TST in terms of hall use, promotion and advertisement due to the lack of theater

\footnotetext{
1 Prof., Aydın Adnan Menderes University, Aydın, Turkey, shakdede@adu.edu.tr
} 
people in the first years of TST, is now subject to change. As in many other fields, the state must first complete infrastructure investments (hall, stage, etc.) in the field of culture and art. They should establish mechanisms to encourage the emergence of private theaters, and form the support structure for them. However, the fact that the state produces theater by employing civil servants (memur) actors and directors brings various economic, political, and social problems.

\section{Financial Aid to Theatres}

Baumol and Bowen $(1965,1966)$ develop the concept of cost disease for theoretical support for government subsidies to performing art companies in the USA. Loyland and Ringstad (2007) investigates benefits and costs of government subsidies to theatres in Norway, whereas Zieba (2009) studies the income and price elasticities of German public theatres.

Below, the total amount of the financial assistance provided by the General Directorate of Fine Arts in the Ministry of Culture of Turkey, in other words, the financial assistance provided to all the types of theater (professional private theaters, professional children's theaters, amateur theaters, traditional theaters) outside the municipal theatres will be given. Then there will only be figures and explanations for assistance to professional private theaters.

Table 1. State Aid and Some Other Related Statistics

\begin{tabular}{|l|l|l|l|l|l|l|}
\hline Years & $\begin{array}{l}\text { All private } \\
\text { theatre } \\
\text { types } \\
\text { State Aid } \\
\text { (TL) }\end{array}$ & $\begin{array}{l}\text { Subsidized } \\
\text { number of } \\
\text { plays }\end{array}$ & $\begin{array}{l}\text { Average } \\
\text { Amount of } \\
\text { Aid } \\
\text { (TL) }\end{array}$ & $\begin{array}{l}\text { Aid per TST } \\
\text { Budget }\end{array}$ & $\begin{array}{l}\text { Number } \\
\text { of TST } \\
\text { Productions }\end{array}$ & $\begin{array}{l}\text { Subsidized } \\
\text { Number of } \\
\text { Productions } \\
\text { / Number of } \\
\text { TSTproductions }\end{array}$ \\
\hline 2008 & 1500000 & 76 & 19736.84 & 0.015 & 115 & 0.661 \\
\hline 2009 & 2500000 & 111 & 22522.52 & 0.022 & 125 & 0.888 \\
\hline 2010 & 3000000 & 152 & 19736.84 & 0.024 & 146 & 1.041 \\
\hline 2011 & 3500000 & 138 & 25362.32 & 0.024 & 135 & 1.022 \\
\hline 2012 & 3445000 & 162 & 21265.43 & 0.022 & 152 & 1.066 \\
\hline 2013 & 4000000 & 178 & 22471.91 & 0.022 & 143 & 1.245 \\
\hline 2014 & 4312000 & 221 & 19511.31 & 0.023 & 151 & 1.464 \\
\hline 2015 & 4265000 & 227 & 18788.55 & 0.021 & 151 & 1.503 \\
\hline 2016 & 4590000 & 235 & 19531.91 & 0.020 & 139 & 1.691 \\
\hline 2017 & 5000000 & 216 & 23148.15 & 0.020 & 148 & 1.459 \\
\hline
\end{tabular}

Source: Author's own calculations

As can be seen from the table, the amount of subsidy to all the theaters except for the accredited government theaters was about two percent of the TST spending budget. The average amount of subsidy is around 20 thousand TL. There was no significant increase in the average amount of subsidy from 2008 to 2017. Considering the inflation rate over the years, it should be said that the amount of real support may not be increased or decreased. The number of plays supported seems to be increased over the years. The ratio of the number of supported plays to the number of TST plays has increased steadily over the years. This should be a gratifying situation. New theater groups are emerging. Unfortunately, we cannot see how stable the new theater groups are. While the ratio of the number of private theater plays supported by the state to the number of TST plays increases continuously, the ratio of the aid given to the private theater plays to the TST budget remains the same, indicating that the amount of aid per play 
has not increased much, and even some years may have decreased. This situation can be seen from the table above. We have already emphasized that the above table includes amateur and traditional theaters. Amateur theaters are very important in terms of spreading the theater, introducing both the art of theater and the active participation of the public in the places where the professional theater does not reach. This should be supported since amateur theaters benefiting from the support are very successful in maintaining the art of theater in their cities.

\section{Data and Statistical Analysis}

After examining the data on all types of the theater, it is useful to examine professional private theaters. These theaters are professional private theaters in the Western sense besides the accredited theaters (TST and city theaters). It should be noted that these theaters, TSTs and city theaters can be free to play and say the games they cannot play or the words they will not say for various reasons (political reasons rather than economic). This will increase cultural diversity. In addition, the censorship mechanism or the mechanism of auto-censorship in the event of the difference between the private theaters and state theaters can be eliminated. First of all, we will evaluate the professional private theaters statistically by means of various data.

Table 2. Descriptive Statistics about Private Theatres

\begin{tabular}{|c|c|c|c|c|c|c|c|c|c|}
\hline & Season & $\begin{array}{l}\text { Nominal } \\
\text { Aid (TL) }\end{array}$ & $\begin{array}{l}\text { Reel Aid } \\
\text { (TL) }\end{array}$ & $\begin{array}{l}\text { National } \\
\text { Play Ratio }\end{array}$ & Total Cast & $\begin{array}{l}\text { Single Ticket } \\
\text { Price (TL) }\end{array}$ & $\begin{array}{l}\text { Discounted } \\
\text { Ticket Price }\end{array}$ & $\begin{array}{l}\text { Male Author } \\
\text { Ratio }\end{array}$ & $\begin{array}{l}\text { Istanbul } \\
\text { Groups }\end{array}$ \\
\hline Mean & 2016-17 & 24.43 & 22.01 & 0.75 & 7.48 & 37.23 & 28.51 & 0.84 & 0.74 \\
\hline Max. & 2016-17 & 72.00 & 64.86 & 1.00 & 110.00 & 67.50 & 50.00 & 1.00 & 1.00 \\
\hline Min. & 2016-17 & 0.00 & 0.00 & 0.00 & 1.00 & 0.00 & 0.00 & 0.00 & 0.00 \\
\hline Std. Dev. & 0 & 20.66 & 18.62 & 0.43 & 11.19 & 18.83 & 13.45 & 0.37 & 0.44 \\
\hline Obs. & 145 & 145.00 & 145.00 & 145.00 & 101.00 & 81.00 & 73.00 & 143.00 & 145.00 \\
\hline Mean & 2015-16 & 25.09 & 23.12 & 0.75 & 6.20 & 34.28 & 27.06 & 0.83 & 0.72 \\
\hline Max. & 2015-16 & 68.00 & 62.67 & 1.00 & 22.00 & 67.00 & 56.00 & 1.00 & 1.00 \\
\hline Min. & 2015-16 & 0.00 & 0.00 & 0.00 & 1.00 & 5.00 & 5.00 & 0.00 & 0.00 \\
\hline Std. Dev. & 0 & 18.81 & 17.33 & 0.43 & 4.24 & 14.56 & 11.56 & 0.38 & 0.45 \\
\hline Obs. & 123 & 123.00 & 123.00 & 122.00 & 86.00 & 58.00 & 58.00 & 123.00 & 123.00 \\
\hline Mean & 2014-15 & 23.00 & 21.12 & 0.73 & 7.58 & 33.59 & 23.69 & 0.83 & 0.69 \\
\hline Max. & 2014-15 & 59.00 & 54.18 & 1.00 & 43.00 & 134.00 & 52.00 & 1.00 & 1.00 \\
\hline Min. & 2014-15 & 0.00 & 0.00 & 0.00 & 1.00 & 0.00 & 0.00 & 0.00 & 0.00 \\
\hline Std. Dev. & 0 & 17.75 & 16.30 & 0.45 & 5.96 & 21.53 & 13.37 & 0.38 & 0.46 \\
\hline Obs. & 118 & 118.00 & 118.00 & 117.00 & 83.00 & 58.00 & 53.00 & 115.00 & 118.00 \\
\hline Mean & 2013-14 & 23.50 & 21.74 & 0.75 & 6.47 & 37.22 & 26.83 & 0.91 & 0.76 \\
\hline Max. & 2013-14 & 76.00 & 70.31 & 1.00 & 20.00 & 220.00 & 57.50 & 1.00 & 1.00 \\
\hline Min. & 2013-14 & 0.00 & 0.00 & 0.00 & 1.00 & 5.00 & 3.00 & 0.00 & 0.00 \\
\hline Std. Dev. & 0 & 21.79 & 20.16 & 0.44 & 4.67 & 28.43 & 11.49 & 0.28 & 0.43 \\
\hline Obs. & 106 & 106.00 & 106.00 & 106.00 & 81.00 & 60.00 & 50.00 & 104.00 & 106.00 \\
\hline Mean & 2012-13 & 28.96 & 28.96 & 0.65 & 7.36 & 36.52 & 26.80 & 0.87 & 0.71 \\
\hline Max. & 2012-13 & 87.00 & 87.00 & 1.00 & 19.00 & 67.50 & 56.00 & 1.00 & 1.00 \\
\hline Min. & 2012-13 & 0.00 & 0.00 & 0.00 & 1.00 & 6.00 & 4.00 & 0.00 & 0.00 \\
\hline Std. Dev. & 0 & 27.02 & 27.02 & 0.48 & 4.26 & 12.67 & 10.00 & 0.34 & 0.45 \\
\hline Obs. & 98 & 98.00 & 98.00 & 97.00 & 76.00 & 59.00 & 53.00 & 97.00 & 98.00 \\
\hline
\end{tabular}

Source: Author's own calculations 
Table 2 above shows some descritive statistics about data, from the 2012-2013 season until 2016-2017 season, given by the Ministry of Culture and Tourism, General Directorate of Fine Arts. After giving brief information about descriptive statistics shown in Table 2 above, we will give the results of a simple regression analysis to understand how some of the factors (variables) we believe may affect the amount of aid.

In the five-year period above, the number of the theaters applying for aid in the 2012-2013 season was 98; there is no information on whether these groups have their own theater halls. In the data obtained from the General Directorate of Fine Arts, there is information about the name of the theater group, the amount of aid it receives, the province where the theater group (company) is located and the name of the play it has applied to get help. Based on these data, we have compiled the information for our regression analysis. The fact that some theater groups own their own theater building or hall does not mean that the theater group owns the property of the building. A few private theaters in Turkey have their theatre halls. Ankara Art Theater and Ankara Ekin Theatre in Ankara are important theater groups, which maintain their existence in the relevant period, produce their plays, not in their own property, but their rental spaces. Even if many important professional theater groups in Istanbul do not have a built-in scene, the ownership of the stage does not belong to the theater group. We will perform the regression analysis in the next section without such important information.

\subsection{Regression Analysis}

Table 3. Regression Table

\begin{tabular}{|l|l|l|}
\hline \multicolumn{2}{|l|}{ Method: } & \multicolumn{2}{l|}{ OLS } \\
\hline \multicolumn{2}{|l|}{ Dependent Variable: Amount of Real Valued Aid (TL) } \\
\hline & Coefficient & \multicolumn{1}{l|}{ t-value } \\
\hline Constant & $609231.20^{* * *}$ & 2.29 \\
\hline National Plays & 2573.18 & 0.89 \\
\hline Amount of aid last season & $19537.76^{* * *}$ & 5.82 \\
\hline Istanbul groups & $7065.59 * *$ & 2.27 \\
\hline Cast & $2061.91^{* *}$ & 2.39 \\
\hline Cast ${ }^{2}$ & $-81.00 *$ & -1.87 \\
\hline Date of Establishment & $-303.47^{* *}$ & -2.29 \\
\hline $2016-2017$ season & -5168.21 & -1.28 \\
\hline $2015-2016$ season & -3557.89 & -0.93 \\
\hline $2014-2015$ season & $-8376.44^{* *}$ & -2.17 \\
\hline $2013-2014$ season & -6500.89 & -1.39 \\
\hline Observation & 184 & \\
\hline F-Value (Prob.) & $6.76(0.00)$ & \\
\hline Adj-R ${ }^{2}$ & 0.24 & \\
\hline$* *$ p<0.01, **p<0.05, $*<0.10$. & & \\
\hline
\end{tabular}


The season variables in the above regression table (2017, 2016, 2015 and 2014) are the dummy variables showing the real amounts of aid in the related years according to the reference year of 2013. The stars placed on the figures help us understand whether the variable makes a statistically significant difference. When we look at the season variables, except for 2015, when compared with 2013, the aid made in other years did not differ significantly in real terms. The coefficients are actually negative. In other words, the aid provided in other years has decreased, however this is not a statistically significant reduction. For 2015, this decrease is statistically significant. In other words, the aid made in 2015 is less in real terms than in 2013. Although there is more aid for domestic plays, this difference is not a statistically significant. In other words, the groups producing the plays of the native writers did not receivemore support because they produced national plays. Theatrical groups with higher number of actors have received more support. Besides, this variable shows a non-linear relationship; groups with too many actors received less support. Cast size of 12.62 (2061.91 / 162) actors (cast) was found to be the maximizing number of cast for highest subsidy, ceteris paribus. In other words, for example, a group of 10 actorsreceived more subsidy from another group of 9 players. On the other hand, agroup, which had 13 actors (cast), received less subsidy than a 12-actor group. The subsidy of a theater group in previous season, ceteris paribus, made it easier to get help this year because the related variable (last year's subsidy) is statistically significant and positive. Therefore it is important to get first subsidy for the theaters because once again, the possibility of getting subsidy again in the following season increases.

The Istanbul theaters received more subsidy than the other theater groups. This should not be surprising because most of the theaters are located in Istanbul, as previously emphasized.

\section{Conclusion}

In this study, the market structure of private theaters and state subsidy to private theaters were examined. What is more important is that there should be assistance in finding audiences, especially in terms of facilitating the entry of the newly established theaters into the sector. In this regard, it is very important that TST owns several stages and halls are ready for the performances of private theaters especially on Mondays. In addition, the separation of public spots into the promotion of private theater plays is important to increase the demand. The construction of at least 100 square meters of rehearsal spaces will also help to develop private theaters so that banners can be printed and the old decors of TST should be available for private theatres usage, and the private theaters can store and rehearse the decors. The cost of these rehearsal spaces to the state will not be very high. Similarly to the construction of the film plateaus, rehearsal spaces can be built in one area of the city. these rehearsal venues should be used by not only theater groups but also music and other performing arts (dance) groups. 


\section{References}

Baumol, W.J. ve Bowen W.G. (1965) "On the Performing Arts: The Anatomy of Their Economic Problems". American Economic Review, 55: 495-502.

Baumol, W.J. ve Bowen W.G. (1966) "Performing Arts-The Economic Dilemma". The Twentieth Century Fund. New York.

Zieba, Marta .(2009). Full-income and price elasticities of demand for German public Theatre, Journal of Cultural Economics, 33 (2) , 85-108.

Loyland, K. ve Ringstad V. (2007) “Norwegian subsidized theatres-failure or future?", International Journal of Cultural Policy, Vol. 13, Issue:4, 407-417. 